\title{
THE ROLE OF PARLIAMENT IN CURBING CORRUPTION: AN ILLUSTRATIVE APPROACH REGARDING PESHAWAR, PAKISTAN
} Bashir Muhammad $^{1 *}$, Mussawar $\mathrm{Shah}^{2}$, Asadullah ${ }^{3}$, Naushad Khan ${ }^{4}$

${ }^{1 *}$ Ph.D., Scholar, Department of Rural Sociology, The University of Agriculture Peshawar, Pakistan; ${ }^{2}$ Chairman/Professor, Department of Rural Sociology, The University of Agriculture Peshawar, Pakistan; ${ }^{3}$ Assistant Professor Rural Sociology, The University of Agriculture Peshawar, Pakistan; ${ }^{4}$ Assistant Professor, Institute of Development Studies, University of Agriculture, Peshawar, Pakistan.

Email: ${ }^{1 *}$ mbashir007@gmail.com, ${ }^{2}$ dr.mussawarshah@aup.edu.pk, ${ }^{3}$ asadpsh@aup.edu.pk, ${ }^{4}$ drkhan@aup.edu.pk Article History: Received on $29^{\text {th }}$ May 2021, Revised on $15^{\text {th }}$ June 2021, Published on $19^{\text {th }}$ June 2021

\section{Abstract}

Purpose of the study: This study aimed to explore the association between the role of parliament and perception of the National Accountability Bureau (NAB) paradigm for curbing corruption in Peshawar.

Methodology: A stratified random sampling technique was used to gather information from 320 sample respondents through an interview schedule. The gamma and chi-square test was applied to determine the association between dependent and independent variables.

Main Findings: Parliament's role was termed as of paramount importance in curbing corruption. There was a significant association between the vital function of parliament in curbing corruption $(\mathrm{P}=0.000)$, introduce new anti-corruption laws $(\mathrm{P}=0.016)$, parliament assure the accountability of executives $(\mathrm{P}=0.003)$, parliament should work with other institution $(\mathrm{P}=0.034)$, Public Account Committee's role is admirable in parliament $(\mathrm{P}=0.815)$, non-accountability of powerful $(\mathrm{P}=0.022)$, parliament should introduce a strict law $(\mathrm{P}=0.017)$ and perception of the NAB paradigm for reducing corruption.

Applications of this study: The results of this research work can be applied to all watchdogs' institutions for its policymaking.

The originality of this study: The study is unique because the information was aggregated directly from the people in the research area.

Keywords: Corruption, Parliament, NAB, Peshawar, PACs.

\section{INTRODUCTION}

Corruption is the encroachment of rule by the lawmakers, government workers, and civil servants, for private advantages, regardless of whether for accumulating riches or for some other political benefits (Nye, 1967; World Bank, 1997). Nye's definition has filled in as an operational definition for various resulting examines (Agbiboa, 2012). Any public office, which bargains in getting cash for its public interests for which he is paid by the state comes into the space of corruption. Sadiq \&Abdullahi (2013) demonstrates corruption as willful encroachment for personal profitable finishes, of systems legitimately, morally, and proficiently either in the private or in the open sector. World Bank and the Transparency International (TI), corruption means unlawful advantages inferred by a public office holder or any outsider noteworthy of holding a public office (Atelhe \& Agada, 2014).

Corruption is named to be as old as human civilization (Rothstein \& Varraich, 2017). Corruption is an illness which is existed in the developed countries alongside non-industrial countries also. It is viewed as with exceptional portrayal of shortening the financial productivity of a state. Mauro (1995) communicated that private investment diminishes due to corruption which decreased economic growth. A large portion of the written works affirms that corruption reduces financial development (Talent \& Keefer, 1995; Hung Mo, 2001; Pellegrini \& Gerlagh, 2004; Guillaumeméon \& Sekkat, 2005). Consistently around one trillion, US\$ is given in pay-off cases every year on the world as indicated by Global appraisals (World Bank, 2004). Without a doubt, corruption stays a colossal hindrance in accomplishing monetary, social, social, and political fundamental liberties (Viljoen, 2012; Hemsley, 2015; Peters, 2016).

Because of the association and unification of human rights, corruption abuses all rights, be social, monetary, political, cultural, and development rights (Murray \& Spalding, 2015; Hemsley, 2015). This because corruption mutilates financial motivations to contribute, sabotages public foundations, rearranges riches and influence to the undeserving, advances resource stripping and the illicit fare of assets, and creates doubt inside the society (Everett et al., 2007; Klitgaard, 2006; Rothstein \& Varraich, 2017). The World Economic Forum estimates that the expense of corruption is US\$ 2.6 trillion, which rises to over 5\% of worldwide Gross Domestic Product (GDP), and that bribery builds the cost of working together by up to $10 \%$ (Thomson, 2017). The yearly payment of pay off alone is assessed to around $2 \%$ of worldwide GDP (IMF, 2016).

Even though corruption is a worldwide issue notwithstanding, its implications with helpless nations are extreme (Olken \& Pande, 2012). The more significant part of the countries set up anti-corruption organizations to check corrupt practices (Meagher, 2005), where Singapore's anti-corruption office and Hong Kong's anti-corruption office are best (Quah, 1989. 
2003, 2006, 2008 2016, 2017a, 2017b \& 2017c). As per the Corruption Perceptions Index 2020, the five least corrupt countries on the planet are Singapore, New Zealand, Denmark, Finland, Switzerland, just as Sweden. At the same time, most Asian nations like Venezuela, Syria, Somalia, Yemen, and South Sudan are terrible countries of the world (TI, $\underline{2021)}$.

Moreover, corruption has additionally been classing as grand corruption, which incorporated official standards, political gifts, and public trust in legislators and petty crime, which included fare and import license, charge installment, all sort of agreements, advances, strategies, and legal choices (Lambsdorff, 2005).

The absence of transparency and accountability additionally assumes a significant part in the spread of corruption. It is regularly said that, where transparency and accountability are missing, crime is legitimate and the other way around. Hence, the shortfall of responsibility and straightforwardness is one of the principal purposes behind the rise and propagation of crime. Corruption arises because of feeble oversight job and failure to rehearse it, and not sticking to the law just as non-enactment of the forces of the administrative bodies over crafted by the organ and considering the guilty party responsible. Different reasons incorporate the feeble managerial obligation, or responsibility for the demonstrations depended on them and the extreme insufficiencies in the utilization of present-day innovative techniques in control frameworks (Yeoh, 2019). Nevertheless, the new similar proof based on cross-sectional analyses specifies an in the reverse connection between corruption and investment, which adversely affects the economy. It very well may be said that the latest investigations have exhibited an opposite relationship between crime and financial development (Qian et al., 2018).

Parliament is the prominent symbol of solidarity regarding social attachment and coordination. Parliament is an establishment declaring the majority support through these chosen agents. This organization is fundamentally destroyed by defining laws and guidelines for containing, coordinating, and foreseeing human conduct. A cross-sectional/cross nations research endeavours led by Djankov et al., (2010) and implied rules relating to admittance to data applicable to parliament individuals with the step taken for nature of government defilement. The fundamental derivation was public exposure and not the data about parliament regarding low corruption and the nature of administration. It was additionally unveiled that the endeavours relationship with lawmaker's resources, income, liabilities on their part, and encounters were found firmly connected with good governance.

Moreover, on a miniature level, Banerjee et al., (2011) made public the connection between political execution and nature of capability may better impact the appointive responsibility with delicate qualities within the institutional edge over the low taught populace portion through arbitrary example methodology in Delhi, (India).

A few nations have been found an absence of responsibility towards completing reforms. Reports over Mozambique revealed that even though, advancement is seen in proclamations of purposes notwithstanding, still, corruption is an issue of immediate consideration (Batley et al., 2006). Similarly, the Burkina Faso report revealed some earnest consideration of the givers to consent to government endeavours of battling against corruption (Lanser et al., 2006). On the spending plan concerning responsibility, the different reports unveiled such occasions have negligible effects. The Nicaragua study revealed the evidence of high comprehensive commitment over transparent execution dependent on transparency in the evaluation of the framework through authentic budget support (Gosparini et al., 2006).

Parliament strength according to controlling corruption was discovered delicate in the political field with an obvious explanation of specific components impacting the donor's presentation (Batley et al., 2006). Uganda's concentrate comparably implied the profundity and speed alongside the course of progress to zero in on technocratic revisions through discussions relating to responsibility interaction may expand. The administration yet homegrown agreement; however, individuals from the parliament of the everyday society may redirect the partners with deluding data in regards to the state (Lister et al., 2006).

\section{Objectives of the study}

1. To measure the perception of respondents in NAB struggling to curb corruption.

2. To assess the association of institutional dysfunctional with perception on NAB fights of limitation corruption concerning rural uplift.

\section{RESEARCH METHODOLOGY}

The present study was carried out in Peshawar, Khyber Pakhtunkhwa, Pakistan, through a cross-section design (Ullah \& Muhammad, 2020), with the primary purpose to explore the role of parliament in curbing corruption. A stratified random sampling procedure of probability sampling was carried out. The total population size was determined as 1872 persons, representing the judiciary, the NAB staff, and local bodies. A sample size of 320 has been chosen as per Sekaran (2016) criteria. The regional body's leaders, officials from the watchdog institutions (NAB, Anti-corruption, FIA) and judiciary were the potential population of the present research study. See table 1 for detail.

Table 1: showing the distribution of population and sample size

\begin{tabular}{lll}
\hline Category & Population & Sample size \\
\hline
\end{tabular}




\begin{tabular}{lll}
\hline Local bodies & 1438 & 246 \\
\hline NAB staff & 421 & 72 \\
\hline Judiciary & 13 & 2 \\
\hline Total & 1872 & 320 \\
\hline
\end{tabular}

\section{Conceptual framework}

The conceptual framework including background variables, dependent variable, and independent variable as given in table 2 below;

Table 2: Conceptual framework

\begin{tabular}{|c|c|c|}
\hline Background Variables & Independent variables & Dependent Variable \\
\hline $\begin{array}{ll}\text { 1. } & \text { Income } \\
\text { 2. } & \text { Qualification }\end{array}$ & Role of parliament & Perception on NAB paradigm for curbing corruption \\
\hline
\end{tabular}

\section{RESULTS/FINDINGS/DISCUSSION/ANALYSIS}

\section{Uni-variate Data Analysis}

Table 3 illustrated that $(66.9 \%),(53.4 \%)$ and $(55.0 \%)$ of the respondents opined that parliament has a vital role in fighting corruption, introducing new anti-corruption laws as the prevalent are old-fashioned and to make sure accountability of administration or executive through administrative check. It is clear from these inferences that people of the area liked the process of accountability and desired its continuation in the shape of making new laws and checks and balances. These findings have similarity to the conclusions of Hague \& Harrop (1982), who of the view that with framing the legislation, a laborious check is also kept these laws more productive.

The data further disclosed that $(65.3 \%)$ and $(65.6 \%)$ of respondents expressed their views and said that corruption is breeding due to the non-accountability of the powerful and for rural uplift parliament must frame laws. Similarly, (55.6 $\%)$ and (46.9 \%) of respondents assumed that to eradicate corruption, parliament should collaborate with other institutions, and in parliament, Public Account Committee is not marvellous to curb corruption, respectively. These outcomes suggested that people exposed the contribution of parliament, albeit Public Account Committees' role is not admirable. These findings were in contradicted the conclusions of McGee, (2002), who appreciated the role of Public Accounts Committees (PACs) in limiting corrupt practices as its function is vibrant in checking the state's affairs about the use of public accounts.

Table 3: Respondents' attitude towards parliament

\begin{tabular}{lllll}
\hline Role of Parliament & Agree & Disagree & Uncertain \\
\hline $\begin{array}{l}\text { Parliament has an active role in fighting corruption by } \\
\text { framing/reframing rules/regulations. }\end{array}$ & $214(66.9)$ & $60(18.8)$ & $46(14.3)$ \\
$\begin{array}{l}\text { Parliament should introduce new anti-corruption laws as the prevailing } \\
\text { ones are obsolete. }\end{array}$ & $171(53.4)$ & $122(38.1)$ & $27(8.5)$ \\
\hline $\begin{array}{l}\text { It is the responsibility of parliament to sure accountability of the } \\
\text { administration or executive through a constant administrative check. }\end{array}$ & $176(55.0)$ & $115(35.9)$ & $29(9.1)$ \\
\hline $\begin{array}{l}\text { For accountability, parliament should work with other institutions and } \\
\text { eradicate corruption. }\end{array}$ & $178(55.6)$ & $116(36.3)$ & $26(8.1)$ \\
\hline $\begin{array}{l}\text { The role of the public account committee in parliament is admirable in } \\
\text { curbing corruption }\end{array}$ & $92(28.8)$ & $150(46.9)$ & $78(24.3)$ \\
\hline $\begin{array}{l}\text { The Non-accountability of the powerful people is a cause of } \\
\text { corruption, and these powerful people are part of parliament as } \\
\text { members. }\end{array}$ & $209(65.3)$ & $73(22.5)$ & $38(11.9)$ \\
\hline $\begin{array}{l}\text { Parliament must focus to frame laws by taking into consideration the } \\
\text { rural uplift schemes. }\end{array}$ & $210(65.6)$ & $67(20.9)$ & $43(13.4)$ \\
\hline
\end{tabular}

\section{Bivariate Analysis}

\section{Association between role parliament and perception on NAB paradigm to curb corruption}

Table 4 shows a positive $(\gamma=0.206)$ but significant $(p<0.05)$ association between the critical role of parliament in the fight against corruption by framing laws and perception of the NAB paradigm for curbing corruption. These inferences were similar to the findings of The World Bank Institution (WBI) which said that for good governance and elimination of crime, the parliament's role should be consolidated in manipulating laws and paradigms. The relationship between perception of the NAB paradigm for curbing corruption and the introduction of new anti-corruption rules by parliament was found significant $(\mathrm{p}<0.05)$ and positive $(\gamma=0.035)$. These findings were in line with African Governance Report (2005), which stated parliament's role to check the country's policies by debating issues in a country is admirable; however, due to the low level of capability of the parliamentarian, it becomes unproductive in terms of deliverance. 
Moreover, the relationship between perception of the NAB paradigm for curbing corruption and parliament's responsibility to ensure accountability of executive and administration by administrative check was originated positive $(\gamma=0.147$ and significant $(p<0.05)$. These outcomes were in line with the findings of Fish (2005), who viewed that the role of the legislature in framing laws and regulations is viable in curbing corrupt practices in the rank and files of the society. To cross-check the politicians' role, parliament formulating methodologies exclusively implemented through administration (Linz, 1990; Linz \& Stepan, 1996; Bailey \& Valenzuela, 1997).

Nevertheless, a non-significant but positive $(\gamma=0.032)$ relationship has revelled between the admirable role of the Public Account Committee in parliament and the perception of the NAB paradigm for curbing corruption. These findings disclosed that the part of Public Account Committees is to curb corruption; however, they are yield less in term of positive effects. These findings were in line with McGee (2002) who also acknowledged the role of Public Account Committees with the tasks mentioned above in parliament. Likewise, a relationship $(\gamma=0.039)$ and $(p<0.05)$ between parliament collaboration with other institutions to curb corruption and perception of the NAB paradigm for reducing corruption was discovered. These findings indicated that strong the liaison between the above described, high would be in the outcomes and transparency. According to Amundsen (1999), the role of parliament indispensable in defining power. Moreover, the mutual part of government and opposition would yield positively. In addition, a significant $(\mathrm{p}<0.05)$ but, positive $(\gamma=0.079)$ relationship revealed between non-accountability of powerful as a cause of corruption and perception on NAB paradigm for curbing corruption. In a society, everyone is subjected to the process of accountability, but if influential people are not brought to the ambit accountability, then there would be no transparency. According to Fish(2005), to accelerate responsibility, powerful legislatures must be available otherwise; it breeds corruption.

Similarly, the relationship between parliament introduces laws about rural uplift and perception of the NAB paradigm for curbing corruption was positive $(\gamma=0.158)$ and significant $(\mathrm{p}<0.05)$. As divulged from these inferences legislative body's role is prominent. For social reformation, there should introduce new laws. The eradication of corruption from society is not easy, as coined by $\underline{\operatorname{Sen}}$ (1999). The role of parliament to regulate human behavior; there should be realistic modes of operations. Such initiatives are necessary if we want to put the system on transparent paths (Packenham, 1970).

Table 4: Association between the role of parliament and perception on NAB paradigm for curbing corruption

\begin{tabular}{|c|c|c|}
\hline Independent variables & Dependent variables & Statistics \\
\hline \multicolumn{3}{|l|}{ Role of parliament } \\
\hline $\begin{array}{l}\text { Parliament has a vigorous role in fighting corruption by } \\
\text { framing/reframing rules/regulation. }\end{array}$ & $\begin{array}{l}\text { ion on NAB paradigm } \\
\text { ing corruption }\end{array}$ & $\begin{array}{l}\chi^{2}=\quad 33.820 \\
(0.000) \\
\gamma=0.206\end{array}$ \\
\hline $\begin{array}{l}\text { Parliament should introduce new anti-corruption laws as the } \\
\text { prevailing are obsolete. }\end{array}$ & on on NAB & $\begin{array}{l}\chi 2=12.248 \\
(0.016) \\
\gamma=-0.035\end{array}$ \\
\hline $\begin{array}{l}\text { It is the responsibility of parliament to sure accountability of the } \\
\text { administration or the executive through a constant administrative } \\
\text { check. }\end{array}$ & $\begin{array}{l}\text { on on NAB p } \\
\text { ing corruption }\end{array}$ & $\begin{array}{l}\chi 2=15.896 \\
(0.003) \\
\gamma=0.147\end{array}$ \\
\hline $\begin{array}{l}\text { Non-accountability of the influential people is a cause of } \\
\text { corruption, and these influential are part of parliament as } \\
\text { members. }\end{array}$ & $\begin{array}{l}\text { perception on } 1 \\
\text { for curbing corru }\end{array}$ & $\begin{array}{l}\chi 2=11.404 \\
(0.022) \\
\gamma=0.079\end{array}$ \\
\hline $\begin{array}{l}\text { The role of public account committee in parliament is admirable in } \\
\text { curbing corruption }\end{array}$ & $\begin{array}{l}\text { perception on NAB paradigm } \\
\text { for curbing corruption }\end{array}$ & $\begin{array}{l}\chi 2= \\
1.565(0.815) \\
\gamma=0.032\end{array}$ \\
\hline $\begin{array}{l}\text { Parliament should introduce strict laws of accountability by } \\
\text { including the new manifestations of corrupt practices. }\end{array}$ & $\begin{array}{l}\text { perc } \\
\text { for }\end{array}$ & $\begin{array}{l}\chi 2=12.015 \\
(0.017) \\
\gamma=0.187\end{array}$ \\
\hline $\begin{array}{l}\text { Parliament must focus to frame laws by taking into consideration } \\
\text { the rural uplift schemes. }\end{array}$ & $\begin{array}{l}\text { perception on NAB paradigm } \\
\text { for curbing corruption }\end{array}$ & $\begin{array}{l}\chi 2= \\
11.831(0.019) \\
\gamma=0.158\end{array}$ \\
\hline
\end{tabular}

Multivariate Analysis

Association between the role of parliament and perception on NAB paradigm for curbing corruption controlling literacy

The association between the role of parliament and perception on NAB paradigm for curbing corruption was founded positive $(\gamma=0.130)$ but non-significant $(p>0.05)$ for the illiterate and positive $(\gamma=0.154)$ and significant $(p<0.05)$ for the literate side as given in table 5. A spurious relationship for the illiterate category was existed between these variables while non-spurious for the literate class due to the identical nature of gamma value at the bivariate level. 
The aforementioned findings amply directed towards the gravity of situations of the literate. Moreover, these people had the information of Islamic interpretation, government efforts, and legislations about corruption in a social system. Parliament plays an anchor role in fighting against corruption in society. It is said that parliament has the primary expression of the people's will to curb crime.

Table 5: Association between the role of parliament and perception on NAB paradigm for curbing corruption controlling literacy

\begin{tabular}{|c|c|c|c|}
\hline Lite & ndependent variables & Dependent variables & $\mathbf{S t}$ \\
\hline Illiterate & Role o & 3 paradigm for curbing corruption & $\begin{array}{l}428(0.115) \\
30\end{array}$ \\
\hline Litera & Role of $\mathrm{p}$ & Perception on NAB paradigm $f$ & $\begin{array}{l}\chi 2=15.811(0.003) \\
\gamma=0.154\end{array}$ \\
\hline
\end{tabular}

Also, a negative $(\gamma=-0.079)$ and a non-significant link were explored between the role of parliament and perception of the NAB paradigm for curbing corruption in the low-income group (Table 6). In contrast, in the medium-income group, a positive $(\gamma=0.246)$ but non-significant relationship between these variables was found and, in the high-income category the relationship was positive $(\gamma=0.316)$ and significant $(\mathrm{p}<0.05)$ as well. There is a spurious relationship for low and medium levels while non-spurious for the high-income group. From these results, it is disclosed that medium and high-income groups had faith in curbing corruption, but parliament's role was ineffective. Moreover, according to the high-income group, parliament plays a vibrant role in fighting against corruption. These inferences had similarity to the conclusions of Stapenhurst et al., (2006) that parliament can play an anchor role if it is constitutionally empowering to formulate laws relating to curbing corrupt practices.

Table 6: Association between the role of parliament and perception on NAB paradigm for curbing corruption while income a background variable

\begin{tabular}{llll}
\hline Income & Independent variables & Dependent variables & Statistics \\
\hline Low & Role of parliament & Perception on NAB paradigm for curbing corruption & $\begin{array}{l}\chi 2=7.226(0.124) \\
\gamma=-0.079\end{array}$ \\
\hline Medium & Role of parliament & Perception on NAB paradigm for curbing corruption & $\begin{array}{l}\chi^{2}=4.394(0.355) \\
\gamma=0.246\end{array}$ \\
\hline High & Role of parliament & Perception on NAB paradigm for curbing corruption & $\begin{array}{l}\chi 2=18.146(0.001) \\
\gamma=0.316\end{array}$ \\
\hline
\end{tabular}

\section{CONCLUSION \& RECOMMENDATION}

The study concluded that parliament's role in framing and implementing laws to eliminate corruption from society was widely acknowledged. These inferences strongly endorsed the revision of laws to address loopholes, if any, administrative actions to enforce these laws, the establishment of Public Account Committee to assess cases regularly while focusing on explaining and exploring new manifestations of corrupt practices conspicuously related to rural uplift. The study further examined that literates had a sound belief and acknowledgment regarding the role of parliament in eradicating corruption from society. Moreover, the low-income group did show an inclination towards a dynamic part of parliament to curb and wipe out corruption from the societal orders to be put on the path of smooth deliverance. Awareness of the people with maximum participation in makes elective to parliament on poise personality traits was extended as recommendations in light of the study.

\section{LIMITATION AND STUDY FORWARD}

The present study was limited to Peshawar district, primarily rural areas, and cannot be generalizing to a large extent. Further, the future research must be conducted in all the watchdogs; institutions at the country level.

\section{ACKNOWLEDGEMENT}

The study at hand performed only on an academic basis and has not received any financial support. We, all the coauthors, verify that the current research study is genuine work.

\section{AUTHOR CONTRIBUTION}

Bashir Muhammad is the principal author of this research work who conceived and developed this paper.

Mussawar Shah is the major supervisor and mentors the whole research process.

Asad Ullah carried out the statistical analysis.

Naushad Khan thoroughly readout the paper and removed grammatical mistakes. 


\section{REFERENCES}

1. Agbiboa, D. E. (2012). Between Corruption and Development: The Political Economy of State Robbery in Nigeria. Journal of Business Ethics, 108(3), 325-345. https://doi.org/10.1007/s10551-011-1093-5

2. Amundsen, Inge (1999). Political corruption: An introduction to the issues. Working Paper 99:7, Bergen: Chr.Michelson Institute.

3. Atelhe, A. G.and Agada, A. T. (2014). Re-Visiting Political Corruption and Development in Nigeria under Democratic Rule. Academic Journal of Interdisciplinary Studies, 3(1), 305-314. https://doi.org/10.590 1/ajis.2014.v3n1p305

4. Bailey, John, and Arturo Valenzuela. (1997). "The shape of the future." Journal of Democracy v8, n4 (October 1997): 43-57

5. Banerjee, A.V. (2011). Ghatak, M. Eviction threats and investment incentives. J. Dev. Econ., 74, 469-488. https://doi.org/10.1016/j.jdeveco.2003.07.004

6. Batley, R., Bjørnestad, L. and Cumbi, A. (2006). Evaluation of General Budget Support - Mozambique Country Report. Birmingham: International Development Department, School of Public Policy, University of Birmingham

7. Dijk, V., Frans, and Vos, G. (2020). A Method for Assessment of the Independence and Accountability of the Judiciary. IJCA, 9. 2017. https://doi.org/10.18352/ijca.276

8. Djankov, S., C. McLiesh, T. Nenova, and A. Shleifer, (2001). Who owns the media? World Bank Policy Research Working Paper No. 2620, World Bank, Washington, DC. https://doi.org/10.3386/w8288

9. Everett, J., Neu, D., Rahaman, A.S. (2007). Accounting and the global fight against corruption, Accounting, Organizations and Society, 32(6), 513-542. https://doi.org/10.1016/j.aos.2006.07.002

10. Gosparini, P., Carter, R., Hubbard, M., Nickson, A. and Núñez, L.O. (2006) Evaluation of General Budget Support - Nicaragua Country Report, Birmingham: International Development Department, School of Public Policy, University of Birmingham.

11. Guillaumeméon, P. and Sekkat, K. (2005). Does corruption grease or sand the wheels of growth. Public Choice, 122, 69-97. https://doi.org/10.1007/s11127-005-3988-0

12. Hemsley, R. (2015). Human rights and corruption: States' human rights obligation to fight corruption. Journal of Transnational Legal Issues, 2(1), 1-24.

13. http://www.transparencyinternational/cpi

14. IMF (2016). Corruption: Costs and Mitigating Strategies. IMF Staff Discussion Note SDN/16/05. https://doi.org/10.5089/9781513594330.006

15. INTOSAI (2013). ISSAI 5700 guidelines for the audit of corruption prevention in government agencies, Exposure Draft, available at: www.issai.org Accessed 12.10.15.

16. Klitgaard, R. (2006). Introduction: subverting corruption, Global Crime, 7(3-4), 299-307. https://doi.org/1 $0.1080 / 17440570601063724$

17. Knack, S. and Keefer, P. (1995). Institutions and economic performance: cross-country tests using alternative institutional measures. Economics and Politics, 7, 207-227. https://doi.org/10.1111/j.14680343.1995.tb00111.x

18. Lambsdorff, J.G. (2005). Consequences and Causes of Corruption: What Do We Know form a Cross Section of Countries? Discussion Paper No. V-34-05. Passau: University of Passau.

19. Lanser, P., Dom, C., Orivel, F. and Ouédraogo, J. (2006). Evaluation of General Budget Support - Burkina Faso Country Report, Birmingham: International Development Department, School of Public Policy, University of Birmingham.

20. Linz, J., (1990). The virtues of parliamentarism. Journal of Democracy 1, 84-92. --- and A. Stepan, 1996, Toward consolidated democracies. Journal of Democracy 7, 14-33. https://doi.org/10.1353/jod.1996.0031

21. Linz, J.J \& Stepan, A.C. (1996). Toward Consolidated Democracies. Journal of Democracy, 7(2), 14-33. Retrieved From: http://repi.ulb.ac.be/sites/default/files/contenu/cours/linz-et-stepan1.pdf

22. Linz, Juan J. (1994). Presidential or Parliamentary: Does it make a difference? Juan J. Linz e Arturo Valenzuela (a cura di), The Failure of Presidential Democracy, Baltimora, Johns Hopkins University Press, pp. 3-91.

23. Mauro, P. (1995). Corruption and Growth. The Quarterly Journal of Economics, 110(3), 681-712. https://doi.org/10.2307/2946696

24. McGee, David G. (2002) The Overseers. Public Accounts Committees and Public Spending, London, Commonwealth Parliamentary Association, with Pluto Press.

25. Murray, M. and Spalding, A. (2015). Freedom from official corruption as a human right. Governance Studies at Brookings.

26. Nye, Joseph S. (1967). Corruption and Political Development: A Cost-Benefit Analysis. American Political Science Review, 61(2), 417-27. https://doi.org/10.2307/1953254

27. Packenham, Robert A. (1970). Legislatures and political development. In Allan Kornberg and Lloyd Musolf (eds.) Legislatures in Developmental Perspective. Durham: Duke University Press 
28. Pellegrini, L. and Gerlagh, R. (2004). Corruption's effect on growth and its transmission channels. Kyklos, 57, 429-456. https://doi.org/10.1111/j.0023-5962.2004.00261.x

29. Peters, A. (2016). Corruption as a violation of international human rights. MPIL research paper no. 2016-2018. Robbery in Nigeria. Journal of Business Ethics, 108(3), 325-345.

30. Qian, et al.(2018). Corruption prevention and economic growth: A mediating effect of rule and law. Int'l J. Soc. Sci. Stud. 6 (2018), 128. https://doi.org/10.11114/ijsss.v6i2.2946

31. Quah, J. S. T. (2006). Curbing Asian Corruption. Current History, April: 176179.

32. Quah, J.S.T. (1988). Corruption in Asia with Special Reference to Singapore: Patterns and Consequences, Asian Journal of Public Administration, 10(1), 80-98. https://doi.org/10.1080/02598272.1988.10800199

33. Quah, Jon S.T. (2011). Curbing Corruption in Asian Countries: An Impossible Dream? Bingley, UK: Emerald Group Publishing. https://doi.org/10.1108/S0732-1317(2011)20

34. Quah, Jon S.T. (2014). Curbing Police Corruption in Singapore: Lessons for other Asian Countries. Asian Education and Development Studies, 3 (3), 186-222. https://doi.org/10.1108/AEDS-07-2014-0029

35. Quah, Jon S.T. (2015a). Enhancing the Effectiveness of Taiwan's Anti-Corruption Agencies in Combating Corruption. American Journal of Chinese Studies, 22 (2), 291-307.

36. Quah, Jon S.T. (2015b). Hunting the Corrupt "Tigers" and "Flies" in China: An Evaluation of Xi Jinping's AntiCorruption Campaign (November 2012 to March 2015). Baltimore, MD: Carey tool of Law, University of Maryland.

37. Quah, Jon S.T. (2016). Combating Corruption in Six Asian Countries: A Comparative Analysis. Asian Education and Development Studies, 5(2), 244-262. https://doi.org/10.1108/AEDS-01-2016-0011

38. Quah, Jon S.T. (2017a). Controlling Corruption in Asian Countries: The Elusive Search for Success. In Ting Gong and Ian Scott (eds.), Routledge Handbook of Corruption in Asia. London: Routledge, Chapter 17, pp. 241-261.

39. Quah, Jon S.T. (2017b). Singapore's Success in Combating Corruption: Lessons for Policy Makers. Asian Education and Development Studies, 6(3), 263-274. https://doi.org/10.1108/AEDS-03-2017-0030

40. Quah, Jon S.T. (2017c). Five Success Stories in Combating Corruption: Lessons for Policy Makers. Asian Education and Development Studies, 6(3), 275-289. https://doi.org/10.1108/AEDS-03-2017-0031

41. Rothstein, B., \& Varraich, A. (2017). Making Sense of Corruption. Cambridge: Cambridge University Press. https://doi.org/10.1017/9781316681596

42. Sadiq, M. And Abdullahi, M., (2013). Corruption as the Bane of Nigeria's Development. International Journal of Economic Development Research and Investment, 4(1), 83-93.

43. Sekaran, U. (2003). Research Methods for Business. The USA, Hermitage Publishing Services.

44. Sekaran, U. (2016). Research Methods For Business, A Skill Building Approach, John Willey \& Sons. Inc. New York.

45. Sen, A. (1999) Development as Freedom. Oxford: Oxford University Press

46. Staplehurst, et al. (2006), The role of parliament in curbing corruption, The World Bank, 1818 H Street NW, Washington, DC 20433, USA.

47. Thomson, S. (2017). We waste $\$ 2$ trillion a year on corruption. Here are four better ways to spend that money. Available at https://www.weforum.org/agenda/2017/01/we-waste-2-trillion-a-yearon-corruption-here-are-fourbetter-ways-to-spend-that-money

48. Ullah, A., \& Muhammad, N. (2020). Prevalence of mental health problems among youth involved in street crimes. Rawal Medical Journal, 45(4), 938-942.

49. Viljoen, F. (2012). International human rights law in Africa (2nd ed.). Oxford University Press. https://doi.org/10.1093/acprof:osobl/9780199645589.001.0001

50. World Bank (1997). World Development Report 1997: The State in a Changing World. World Bank, Washington DC.

51. World Bank (2004) http://www.worldbank.org/WBSITE/EXTERNAL/NEWS. www.transparency.org. www.transparency.org.pk/.../CPI2009/CPI20 2009 Press Release November.

52. Yeoh, Peter (2019). The national anti-corruption initiatives in the context of international norms. Mastering Anti-Corruption: The Practitioners' View, 2019, 47. 